\title{
Short Communication: Investigating environmental impacts of long-term monoculture of sugarcane farming in Indonesia through DPSIR framework
}

\author{
RIVANDI PRANANDITA PUTRA ${ }^{1, \boldsymbol{v}}$, MUHAMMAD RASYID RIDLA RANOMAHERA ${ }^{1}$, \\ MUHAMMAD SYAMSU RIZALUDIN ${ }^{2}$, RAHMAD SUPRIYANTO ${ }^{3}$, VITA AYU KUSUMA DEWI ${ }^{4}$ \\ ${ }^{1}$ Pre-Harvest Department, Indonesian Sugar Research Institute. Jl. Pahlawan No. 25, Pasuruan 67126, East Java, Indonesia. \\ Tel.: +62-343-421086, Fax.: +62-343-421178, •email: rivandiprananditap@ gmail.com \\ ${ }^{2}$ Department of Sustainable Agriculture, Institute for Rural Development and Sustainability (Rotasi Institute). J1. Raya Kaliboto-Wonodadi No. 32 , \\ Blitar 66155, East Java, Indonesia \\ ${ }^{3}$ School of Natural and Environmental Science, Newcastle University. King's Road, Newcastle upon Tyne, NE1 7RU, United Kingdom \\ ${ }^{4}$ Department of Agricultural Engineering and Biosystem, Institut Pertanian Bogor. Jl. Raya Dramaga, Bogor 16680, West Java, Indonesia
}

Manuscript received: 21 June 2020. Revision accepted: 7 August 2020.

\begin{abstract}
Putra RP, Ranomahera MRR, Rizaludin MS, Supriyanto R, Dewi VAK. 2020. Short Communication: Investigating the environmental impacts of long-term monoculture of sugarcane farming in Indonesia through DPSIR framework. Biodiversitas 21: 49454958. An increasing trend of sugar demand in Indonesia due to the rising population has forced the government to boost its national sugarcane production through intensification program. Long-term monoculture system has long been practiced by sugarcane growers in Indonesia, particularly by large sugar companies for more than 30 years. This farming method bolsters the government's program in scaling-up national sugar production. Through a literature study, the present study analyzed the impacts of long-term sugarcane monoculture in Indonesia on agroecosystem functions by using the Driver-Pressure-State-Impact-Response (DPSIR) framework. Results showed that long-term sugarcane monoculture leads to decreased soil quality, lowered hydrological functions, reduced agrobiodiversity, and increased greenhouse gas emissions. Those conditions corresponded to reduced sugarcane yield and productivity, increased pests and diseases, decreased income gained by growers, higher dependencies on chemicals, and higher cultivation costs. In the end, we proposed several sustainable crop management to mitigate the detrimental effects of sugarcane monoculture practice in Indonesia. These include performing crop break or rotation with legume or the other cash crop, intercropping, green harvesting and trash blanket, precision agriculture methods, and soil amendment with organic matters. However, some constraints in implementing those sustainable crop management, such as inadequate knowledge and capital, should be considered. The information given in this study can be used by sugarcane growers or companies, policymakers, and sugarcane-related stakeholders as considerations to improve sugarcane productivity while at the same time minimizing its impact on the environment.
\end{abstract}

Keywords: DPSIR, environment, Indonesia, monoculture, sugarcane

\section{INTRODUCTION}

Sugarcane (Saccharum officinarum L.) is one of the essential estate crops in Indonesia, and it has an important role in the country's economy. The increased population and income per capita, as well as a change in diets among the people, leads to the increased demand for cane sugar in Indonesia over the past decades. However, it is not followed by a rise in domestic sugar production. The area of sugarcane plantations is declining over time (NSC 2020), which further hampering sugar production, and therefore increasing the gap between sugar consumption and production in the country (Solomon et al. 2016; Toharisman and Triantarti 2016; Sulaiman et al. 2019). The reduction of the sugarcane plantation area in Indonesia has been linked to several socio-economic factors, such as fluctuation in sugar price, high production costs, the absence of subsidized fertilizers, and farmers' preference to opt for the other crops that are more profitable over sugarcane. In response to such production issue, the Indonesian government, through its Ministry of
Agriculture, had implemented an agriculture intensification program aimed to boost its national sugarcane production. The program, called "Tebu Rakyat Intensifikasi (TRI)", forces landowners to plant sugarcane in their land. This program was introduced in 1975 and ended in 1998.

In some areas of Indonesia, especially in Java and Sumatera Island, lands are converted into sugarcane plantations, in which the monoculture system has been by far a predominant farming practice applied by Indonesian sugarcane growers (Kusumawati et al. 2020). Monoculture refers to the cultivation of single crops within the given area at a time, and in this case, sugarcane is the only crop cultivated by the growers. Sugarcane growers in Indonesia tend to cultivate this crop without rotation systems, meaning that they continuously grow sugarcane throughout farming seasons. Farmers in Java Island, for instance, are encouraged by the Indonesian government to grow sugarcane over the other crops and expected not to shift it into other commodities. Although this farming method supports the government's intensification program, foregoing studies have revealed that long-term sugarcane 
monoculture leads to some ecological problems and reduced crop productivity. Large-scale sugarcane cultivation has been associated with land-use changes; thus, adversely impact the environment, such as causing soil degradation, water, and air pollution, as well as biodiversity loss (Hess et al. 2016; Hawkins 2018).

This study will help to contribute to a better understanding of environmental impacts caused by sugarcane monoculture by identifying possible long-term consequences of such a farming system toward several environmental indicators such as soil quality, hydrological function, agrobiodiversity, GHG emissions, fire risk, and their impacts on socio-economic aspects. This study emphasizes on the environmental side of the long-term sugarcane monoculture. It includes some options for sustainable cultivation management to help in mitigating the problem. The results of this study can be used by sugarcane-related stakeholders as a consideration to improve sugarcane productivity without sacrificing the environment.

\section{MATERIALS AND METHODS}

A Driving force-Pressure-State-Impact-Response (DPSIR) framework was used to generate a comprehensive view concerning possible environmental impacts caused by longterm monoculture cultivation of sugarcane in Indonesia. The DPSIR is a practical framework intended for assessing the impacts of anthropogenic activities on the environment and vice versa since the components within the framework are interdependent. The framework was firstly proposed by Rapport and Friend (1979), then it was adapted and widely introduced by the Organization of Economic and Development (OECD) as a tool for environmental reporting. The DPSIR framework was chosen because of its simplicity and its powerful communication tool linking the environment to society, and vice versa.

A DPSIR framework comprises the following components: driving forces, pressures, states, impacts, and responses (Maxim et al. 2009). Driving forces are the socio-economics or socio-economical facets of human activities determining the magnitude of environmental problems. Pressures are the exposure of ecosystems to the threats due to anthropogenic activities. States are measurements of the changes in environmental conditions. Impacts are the consequences caused by states on biodiversity and ecosystem functioning. Responses are regulatory and strategic actions that society can do to reduce the adverse effects of each of the four prefacing framework components (Hester and Harrison 2007).

\section{RESULTS AND DISCUSSION}

A DPSIR diagram has been drawn according to the literature search and the authors' professional experience related to sugarcane monoculture (Figure 1). Starting from the "Driving forces", the DPSIR diagram is basically a loop-line system that ends at the "Response". In the end, the response addresses the sub-criteria within the Driving forces, symbolized with an arrow. All arrows within the diagram denote the general cause-and-effect relations amongst the framework components. The arrows can be read as something 'leads to' or 'produces' the subsequent box. Double arrows indicate feedback loops.

\section{Driving Forces (D) of long-term monoculture of sugarcane farming in Indonesia}

Indonesia's demand for sugar is rising over time due to the growth of population which has attained $1.3 \%$ annually (Statistics Indonesia 2018; Sulaiman et al. 2019; NSC 2020) (Figure 2), increased income (Sulaiman et al. 2019), as well as growing demand from food and beverage industries (Toharisman and Triantarti 2016). The total world production for sugarcane accounts for up to 1.9 billion tons, while in Indonesia, it reaches up to 2.2 million tons (FAO 2018). Despite accounting only $0.12 \%$ of the total world production, the average growth rate of sugarcane consumption in Indonesia increased by up to $2 \%$ annually since 1996, and in 1997, the government initiated sugar import to the country ( $\mathrm{Pu} 2015)$. To meet the national sugar demand in 2020, for instance, the country needs to import at least 1.5 million tons (NSC 2020). In Indonesia, sugar consumption is intended for both household and industrial uses (Toharisman and Triantarti 2016).

Consumers' dependency on cane sugar is also very high since there is a small tendency to substitute with synthetic sugar or the other artificial sweeteners. In Indonesia, artificial sweeteners have a very segmented market, namely only for diabetic people or persons in a diet program. Sugarcane is a primary sugar-producing raw material in the world, including Indonesia. Sugarcane accounts for $80 \%$ of the sugar produced in the world (Sharma and Chandra 2017). Most of the rest can be made either from sugar beets, palm sugar, stevia, or maize.

The other driving forces for sugarcane growers to implement a monoculture system in their field are the easiness or practicality of doing it and low production cost. In Indonesia, sugarcane is mostly grown for several years, while the whole above-ground biomass is harvested each year. Under-ground parts (roots) remain in the soil since they are expected to re-grow, and this process is called ratooning.

\section{Pressures (P) of long-term monoculture of sugarcane farming in Indonesia}

Due to increased sugar demand in Indonesia, the sugar production needs to be improved via intensifying the cultivation system. In addition to this, lands used for sugarcane cultivation also needs to be expanded (Djajadi 2015). As sugarcane belongs to the $C 4$ plant, it is considered as one of the most efficient photo-synthesizers in the plant kingdom. This feature makes sugarcane can easily grow in tropical regions, such as Indonesia, given the fact that the country has plenty of sunlight throughout the year. Nevertheless, not all areas in Indonesia are suitable for sugarcane cultivation due to variations in soil characteristics as well as climate conditions (Sulaiman et al. 2019). Therefore, sugarcane cultivation in Indonesia is 
intensified in certain areas. In 2018, a total of 10 provinces had become the main sites of sugarcane cultivation in
Indonesia, mostly located on Java Island due to its high soil fertility (Figure 3).

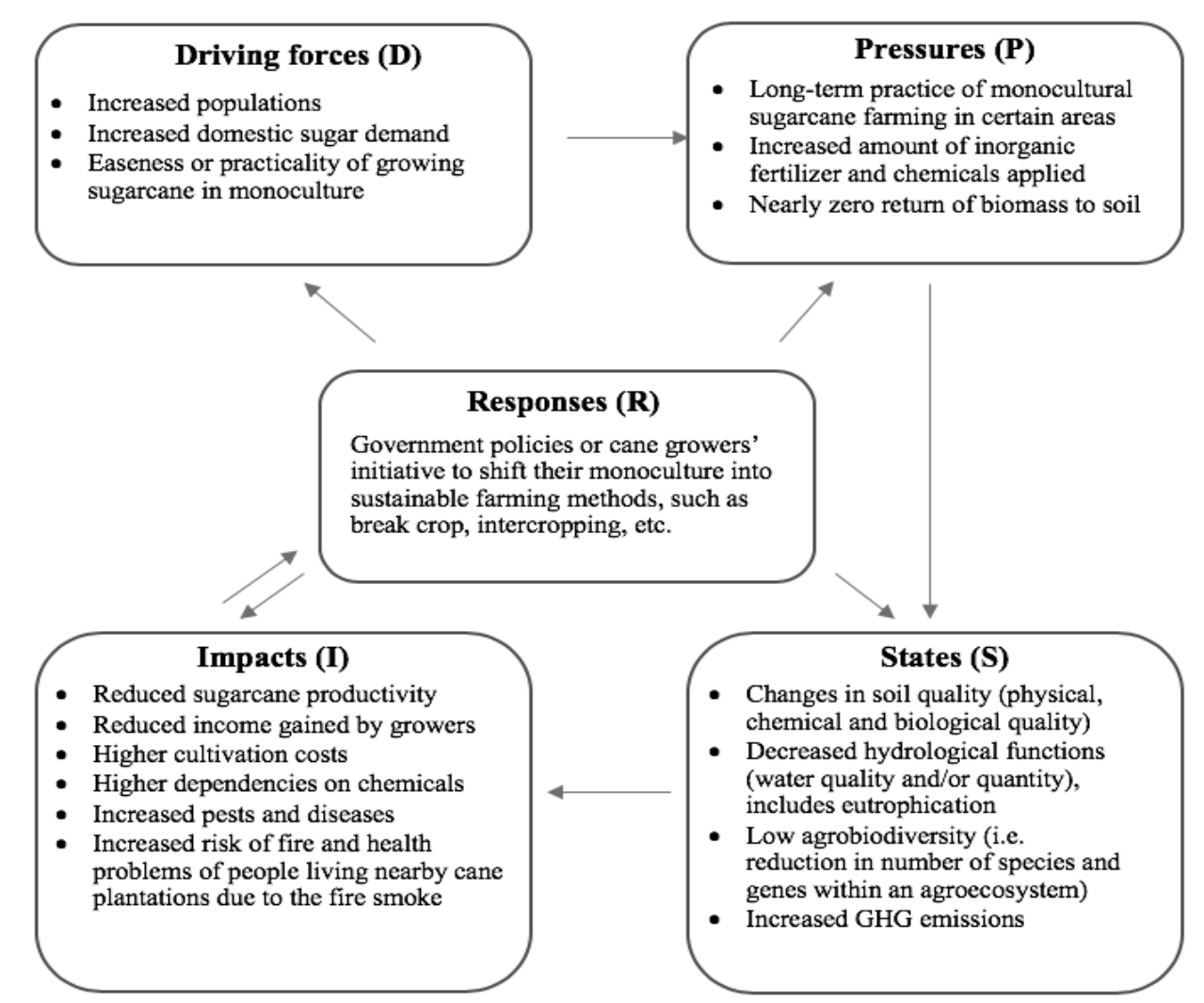

Figure 1. The DPSIR diagram of environmental problem caused by long-term sugarcane monoculture in Indonesia

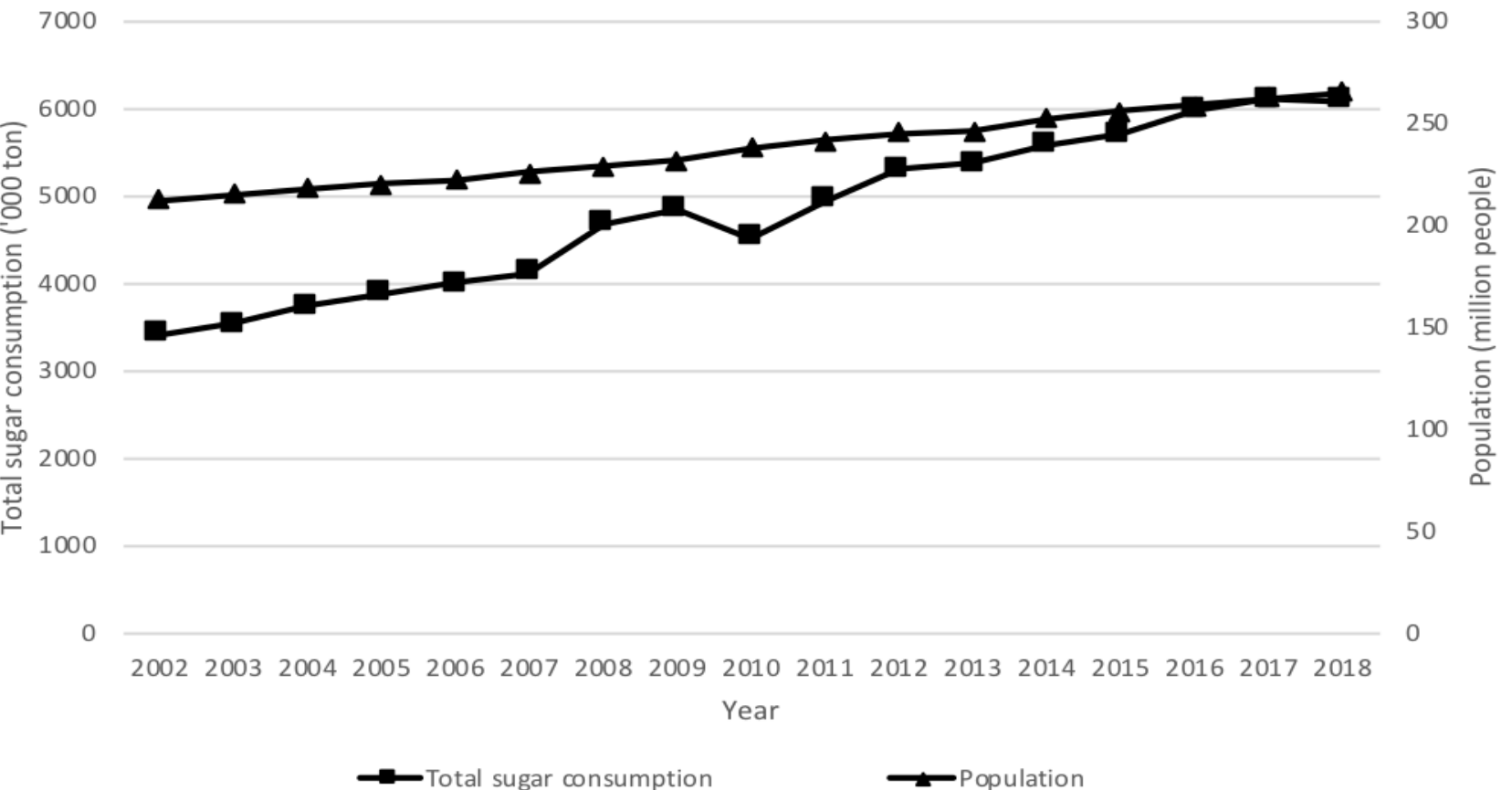

Figure 2. Total sugar consumption (direct consumption + industry) and population growth in Indonesia between 2002 and 2018 (adapted from NSC 2020; Toharisman and Triantarti 2016) 


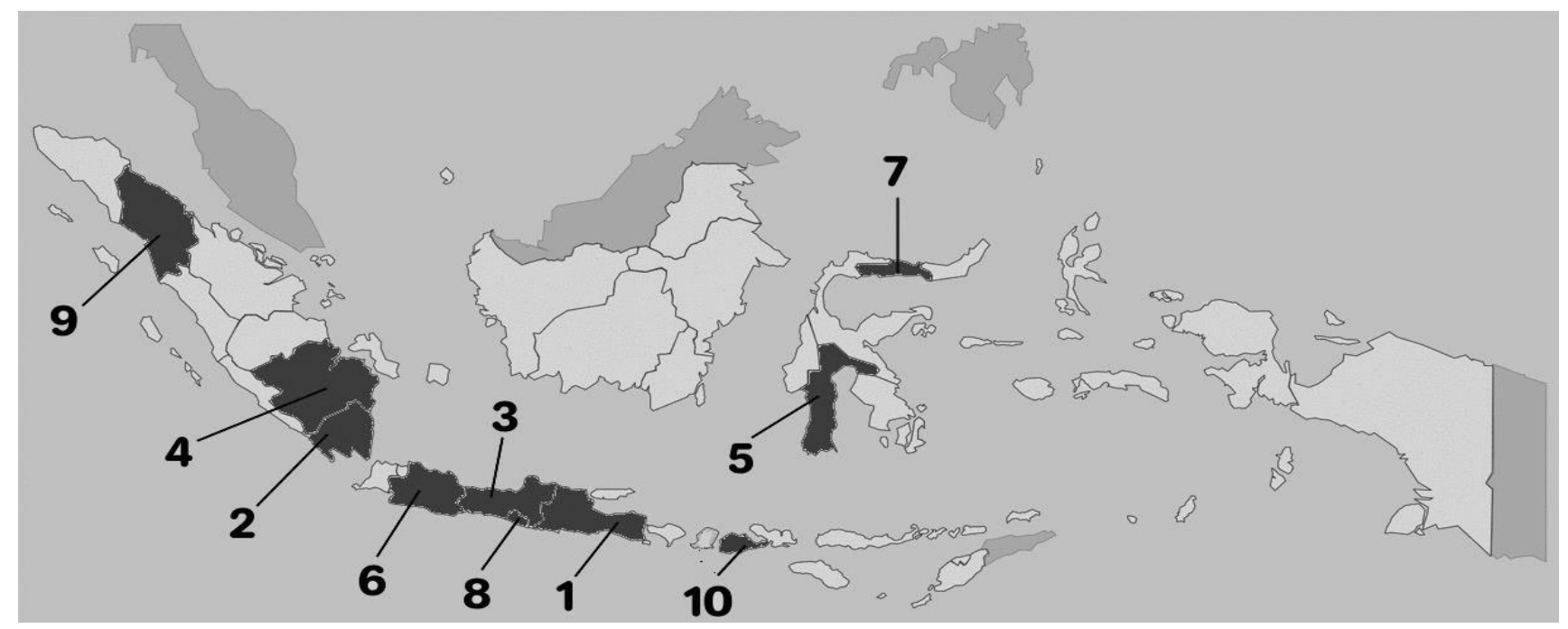

Figure 3. Map of sugarcane plantations distributions across Indonesia in 2018 (adapted from Statistics Indonesia 2018). Note: The numbers on the map show the provincial rank of plantation areas in Indonesia from the largest. 1. East Java (196,897 ha/ 47.4\%), 2. Lampung (109,837 ha/ 26.4\%), 3. Central Java (36,852 ha/ 8.9\%), 4. South Sumatera (21,609 ha/ 5.2\%), 5. South Sulawesi (14,636 ha/ $3.5 \%)$, 6. West Java (14,232 ha/ 3.4\%), 7. Gorontalo (8,242 ha/ 2\%)8. Special Region of Yogyakarta (6,805 ha/ 1.6\%)9. North Sumatera $(6,196 \mathrm{ha} / 1.5 \%) 10$. West Nusa Tenggara (357 ha/ 0.1\%). After 2018, private companies expanded their sugarcane plantations in South East Sulawesi and East Nusa Tenggara.

Figure 2 indicates a close relationship between the growth of the population and total sugar consumption over time in Indonesia. At the beginning of 2002, total sugar consumption in Indonesia reached approximately 3.4 million tons, while the population was about 212 million people. The growth rate of sugar consumption exceeded the population growth and has become closer in 2016 onwards. In 2018, the total sugar consumption and the population number were about six million tons and 265 million people, respectively. This condition implies a linear correlation between population growth and total sugar consumption in Indonesia, which has become the main driving force for the implementation of sugarcane monoculture in the country.

Commercial sugarcane cultivation by monoculture in Indonesia was initiated by Dutch colonials in the 1830s. This adoption of a monoculture system mostly occurs in large-scale sugarcane plantations belonging to the stateowned companies (PT Perkebunan Nusantara/PTPN) or private sugar companies. Sugarcane monoculture in Indonesia often uses extensive synthetic chemicals such as inorganic fertilizers (mainly nitrogen) without considering the current soil nutrient status, as well as pesticides and herbicides (5-15 liter per hectare of ametrine-2,4dichlorophenoxyacetic acid solution) to increase yield. Nitrogen addition, to some extent, support vegetative growth, leading to high biomass (Pawirosemadi 2011). Nevertheless, the situation is somewhat different if the sugarcane is grown by smallholder farmers. The smallholders are very 'volatile' as they may easily change the sugarcane into other crop commodities that are financially more profitable. However, even though the smallholders often suffer from financial losses, many of them still preserve their sugarcane plantations due to farming practicality, higher cost when changing into the other commodities, and an expectation to gain more profit in subsequent harvests (Idris 2016).

Sugarcane is commonly ratooned in Indonesia, and harvest continues for some years. Sugarcane ratooning is profitable as the growers can minimize production costs for soil tillage, seeds, and labor (Srivastava and Rai 2012). However, the maximum period of ratooning is only three years to make the method stays profitable for farmers. After three years, the yield of ratooned plantations tends to decreases and less profitable; thus, it should be re-plowed, and new sugarcane seeds should be planted (Pawirosemadi 2011). Until currently, most Indonesian sugarcane growers are still practicing ratooning for more than three times.

Sugarcane produces high biomass, consisting of stalks and leaves, approximately 100 tons per hectare, mainly from stalks processed into sugar. Sugarcane dry leaves, which account for 5-20 tons per hectare, are left at the field (Sandhu et al. 2017). In Indonesia, the residues are mostly subjected to be burned that may result in nearly zero biomass return to the sugarcane plantation.

\section{States (S) of long-term monoculture of sugarcane farming in Indonesia}

We have identified some possible ecological changes under long-term sugarcane monoculture in Indonesia. A natural land provides habitats for wildlife and serves multifunctional purposes to human life, such as for agriculture, pastoralism, infrastructure development, mining, tourism. It also provides a range of ecosystem services such as soil formation and retention, soil nutrient cycling, species maintenance, biological control, climate regulation, prevention of disturbance and moderation of 
extreme weather, water, air, and soil purification, and many more (Zari 2015). When a natural land is converted into sugarcane plantations, and a conventional monocropping system is applied for a long time, the ecological functions might be reduced. However, the extent to which long-term sugarcane gives drawbacks to the environment varies depending on the type or scale of production and its location (Hawkins 2018).

\section{Decreased soil quality}

Soil quality is the most affected factor caused by a long-term monoculture of sugarcane cultivation. An assessment of soil quality involves three different aspects, namely the physical, chemical, and biological properties of the soil. Soil physical properties refer to the soil morphology, such as texture, color, density, and porosity. The chemical attributes correlate to all chemical forms of the soil, such as $\mathrm{pH}$, organic matter (OM) content, soil nutrient composition, cation exchange capacity (CEC), and chemical composition of the parent material.

Soil quality is greatly influenced by land management, where long-term sugarcane monoculture affects soil physical and chemical properties. Studies regarding the impacts of sugarcane monoculture on soil physical characteristics in Indonesia are scarce, but they are reported by numerous global studies. In a common sugarcane monoculture, for instance, the use of a natural groundcover is scarce, hence making soil erosion is prevalent in this system due to heavy rain or excessive furrow irrigation (Srivastava and Rai 2012). In an agroecological-managed system, a groundcover is usually cultivated along with main crops to protect topsoil from erosion and drought. Sugarcane cultivation can induce negative impacts on soil porosity (reduced $20 \%$ of soil total porosity indicator), soil organic carbon (reduced from $20 \mathrm{~g} / \mathrm{kg}$ to less than 15 $\mathrm{g} / \mathrm{kg}$ ), and soil aggregate stability (changed the micro, meso, and macro-porosity distribution) (Cavalcanti et al. 2020). Soil compaction can also occur in conventional sugarcane cultivation due to the intensive use of heavy machinery during planting and harvesting (Srivastava and Rai 2012; Hawkins 2018). Soil compaction can reduce water infiltration capacity in the soil and, therefore, can intensify erosion due to increased water runoff (Srivastava and Rai 2012). Highly compacted soil can also hamper root proliferation as affected by high mechanical resistance and poor aeration.

Long-term sugarcane monoculture can deplete soil fertility (Chi et al. 2017). Changes in soil physics due to intensive monoculture, such as loss of topsoil and soil compaction, lead to lower levels of nutrients and OM (Savario and Hoy 2011; Hawkins 2018), including soil carbon (Bordonal et al. 2017). Decreased soil quality is also caused by the burning practices of sugarcane residues before and following harvest (dos Santos et al. 2020). In continuous sugarcane monoculture, soil quality may become poor due to improper nutrient management (Srivastava and Rai 2012). Based on a field trial in Yogyakarta, Kusumawati et al. (2020) observed that soil $\mathrm{pH}$ and cation exchange capacity change with the prolonged duration of the sugarcane monoculture system in three different soil types. Continuous application of synthetic fertilizer in a monoculture system might also increase soil electrical conductivity (EC) and induce soil acidification. In the long-term duration, increased soil EC combined with low $\mathrm{pH}$ might adversely affect the yield and the quality of sugarcane. Furthermore, Pinheiro et al. (2010) found the changes in soil chemical parameters, i.e., $\mathrm{pH}$, aluminum, as well as calcium and magnesium, over a 10-year cultivation period of sugarcane monoculture, particularly at a soil depth of $0-30 \mathrm{~cm}$, corresponding to the fluctuated yield.

\section{Decreased hydrological functions}

Sugarcane requires a vast amount of water during its growth stage (Srivastava and Rai 2012; Sulaiman et al. 2019). A minimum of 12 to 18 Megalitre per hectare is needed for each growing season, while the crop water requirement $(\mathrm{CWR})$ for sugarcane $(1,950 \mathrm{~mm} / \mathrm{season})$ was almost doubled the rice's CWR for each growing season $(1,004 \mathrm{~mm} / \mathrm{season})$ (Steduto et al. 2012). To a certain extent, long-term sugarcane monoculture could reduce water availability (Silalertruksa and Gheewala 2018; Sulaiman et al. 2019; German et al. 2020). The absence of water use regulation and management can lead to fierce competition between water users, i.e., local community, natural ecosystems, or growers of the other crops, and sugarcane growers (Sulaiman et al. 2019; Ranomahera and Ritzema 2020). The water supply at the tail-end of the hydrological cycle might be affected severely. For instance, a decline in water quantity due to long-term sugarcane monoculture was reported in Indramayu, West Java (Ivansyah 2015). The condition, in turn, can hamper sugarcane growth since $80 \%$ of sugarcane plantations in Indonesia rely on irrigation (Sulaiman et al. 2019).

Sugarcane monoculture can also lead to the water pollution caused by chemicals, i.e., fertilizers, pesticides, or herbicides flowing into water bodies (Davis et al. 2011; German et al. 2020). The other minor contributors of eutrophication in a sugarcane plantation are $\mathrm{NO}_{\mathrm{x}}$ (nitrous oxide) from sugarcane burning, transportation, and machinery operation (Renouf et al. 2010). The decline of water quality may impact both freshwater and marine ecosystems (Hawkins 2018). In Mojokerto, East Java, there was a report of a quality decline of well water nearby a sugarcane plantation (Budianto 2018). When the water body is rich in nutrients, eutrophication may occur. Purwaningsih (2016) found multiple causes of eutrophication occurred on the water bodies near a sugarcane plantation in Subang, West Java, but $\mathrm{P}$ runoff due to TSP, NPK, and SP-36 fertilization is the greatest contributor to the problem.

\section{Lowered agrobiodiversity}

Agrobiodiversity refers to the variety of species and/or genetic of living organisms within an agroecosystem that plays a vital role in sustaining the ecosystem and in improving crop productivity. Several studies indicated a decrease in agrobiodiversity due to long-term sugarcane monoculture (Netondo et al. 2010; Mwavu et al. 2016; Hawkins 2018). In Malang, East Java, Nurhidayati et al. 
(2011) found a decline in the earthworm population under long-term conventional sugarcane farming. They posited that the condition might be associated with reduced $\mathrm{OM}$ content and the use of mechanical tillage in the system. $\mathrm{OM}$ is important for earthworms and the other beneficial soil macrofaunas, hence the absence of OM in the soil can limit the growth and reproduction of those biotas (MedinaSauza et al. 2019). Whereas the extensive implementation of the tillage system, such as plowing, can severely damage earthworm populations. Sugarcane monoculture systems can also decimate the population of beneficial microbes in the soil (Savario and Hoy 2011).

\section{Increased Green House Gas (GHG) emission}

de Figueiredo et al. (2010) observed that the most drastic GHG emissions during sugarcane farming have resulted from residues burning (44\%), followed by synthetic fertilization (20\%), and fossil fuel combustion from vehicles used to transport sugarcane to sugar factories (18\%). Many Indonesian sugarcane growers burn their plantations before harvesting. At the field level, the burning method poses a dilemma since it can cut labor costs, enable manual workers to harvest sugarcane stalk more easily and quickly, as well as avoid the workers from personal injuries during harvesting. However, at the same time, the burning method of harvesting also causes air pollution (Pongpat et al. 2017). GHG emission in sugarcane fields also comes from the application of manure or inorganic fertilizer, especially N (Galdos et al. 2010; Luo et al. 2016; Wang et al. 2016). Burning method of sugarcane harvesting releases immense levels of $\mathrm{GHG}$, as part of agricultural activities that recorded an increase of GHG emissions from $300 \mathrm{Mt}$ $\mathrm{CO}_{2} \mathrm{e} /$ year in 1990 to $800 \mathrm{Mt} \mathrm{CO}_{2} \mathrm{e} /$ year in 2015, contributing to $5.3 \%$ share of global GHG emissions (Brown to Green report 2017), such as carbon monoxide (CO), ozone $\left(\mathrm{O}_{3}\right)$ (Hawkins 2018), methane $\left(\mathrm{CH}_{4}\right)$, and $\mathrm{N}_{2} \mathrm{O}$ (Galdos et al. 2010). Based on a field trial in Pati, Central Java, Hervani et al. (2017) discovered an average increase of $\mathrm{N}_{2} \mathrm{O}$ gas fluxes of $843 \mu \mathrm{g} \mathrm{N}_{2} \mathrm{O} / \mathrm{m} /$ day in rainfed sugarcane area due to $\mathrm{N}$ fertilization. However, they also suggested that the emission produced depends on the interaction between soil type, climate, and cultivation technique.

\section{Impacts (I) of long-term monoculture of sugarcane farming in Indonesia}

The aforementioned explanation about the "States" induces several situations that will be described as "Impacts". Degraded ecological conditions and lower agrobiodiversity due to long-term sugarcane monoculture are associated with the decreased yield (Altieri et al. 2015) and commercial cane sugar (CCS) (Djajadi 2015). Sugarcane productivity in Bungamayang, North Lampung, and Ogan Ilir, South Sumatera, for instance, has been fluctuating or even declining over time since the beginning of cultivation in 1984. This condition is associated with soil quality degradation, particularly the reduction in soil fertility (Premono et al. 1999). Another example of a gradual decrease in productivity happened in some cultivation areas in Java Island despite that the soils in these places have higher soil fertility. Indeed, areas with high soil fertility can sustain monoculture with reasonably high yields, but numerous studies have shown that after some time, the yields start declining.

Data explicates that Indonesia's sugarcane productivity decreased over time, although the sugarcane plantation areas are expanded (Figure 4). For the last thirty years, to support the plantation development, ISRI has focused on providing high sugar-yielded and agro-specific sugarcane varieties through breeding programs. Nonetheless, it is imperative to know that land degradation is not the only cause of such decline. There may be multiple and complex factors causing the decrease of sugarcane productivity over time in Indonesia. These include the occurrence of climate change or extreme weather, the emergence of new crop diseases and biosecurity issues, the lack of excellent sugarcane varieties, the lack of research and coordination amongst stakeholders in the sugar industry, etc. (Toharisman and Triantarti 2016).

Long-term sugarcane monoculture might gradually increase the cultivation costs. An annual survey of sugarcane cultivation costs conducted by several institutions, such as government agency, sugar industry, university, and ISRI, reported that during 2017-2018 there was a rise of about $15 \%$ in sugarcane cultivation costs (Directorate General of Estate Crops 2017-2018, unpublished report). The decline of soil quality in longterm sugarcane monoculture forces the growers to increase their agronomic inputs such as inorganic fertilizers and chemical pesticides to maintain high productivity.

A combination of long-term monoculture system, the application of chemicals, and the use of certain dominant sugarcane cultivar has contributed to the increased emergence of pests and diseases in the sugarcane cultivation. Currently, there are several reports indicated an increase of pests and pathogens attacks in sugarcane fields over Java and Sumatera Island (ISRI 2019, unpublished report). In Sumatera Island, for instance, Xylaria spp., which is a pathogenic fungus, has spread over thousands of hectares of sugarcane plantations. While in Java Island, the spread of leaf disease become more prevalent in the plantations cultivated by a certain dominant sugarcane cultivar. Lower agrobiodiversity is also responsible for increased pests infestation due to reduced pest natural enemies. Increased vulnerability of sugarcane to pests and pathogens in long-term monoculture systems leads to a higher dependency on chemicals such as pesticides and fungicides. Consequently, growers need to spend higher cultivation costs to buy the chemicals, which at the same time, income gained by the growers might be lower due to reduced yields. 


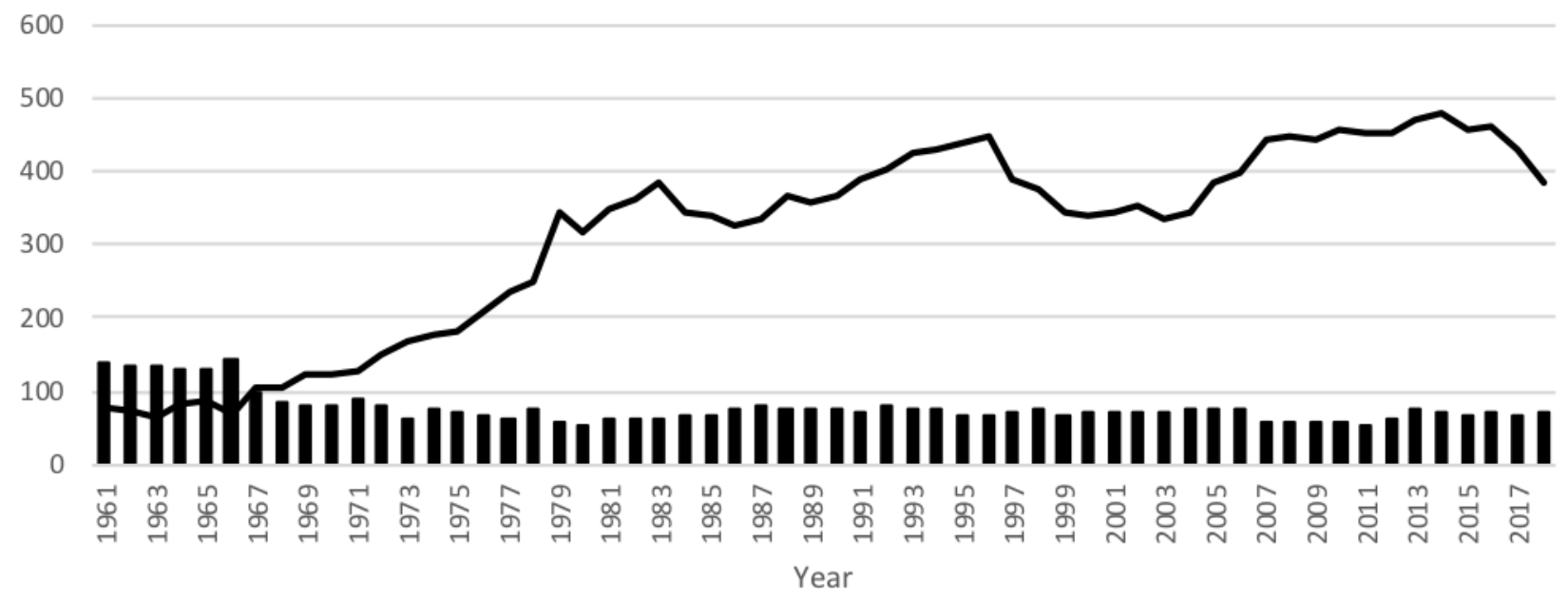

- Sugarcane productivity (tons/ha) I Total plantation a reas ('0000 ha)

Figure 4. Sugarcane productivity and sugarcane plantation areas in Indonesia between 1961 and 2018 (adapted from ISRI 2004; Directorate General of Estate Crops 2016; FAOSTAT 2020; Indonesian Ministry of Agriculture 2020; Our World in Data 2020)

The practice of sugarcane monoculture also enhances the risk of fire in the plantation, especially in dry seasons or when the residues are dry. Fires in the plantations can be triggered by wildfires such as lightning or human activities on site. In some locations, sugarcane trashes are deliberately burned to ease manual cutting (Gonino et al. 2019). Smoke and ash particulate of the fire is often jeopardizing the health of plantation's workers or people living nearby the plantations (Cristale et al. 2012; Mnatzaganian et al. 2015; Paraiso and Gouveia 2015; Le Blond et al. 2017; Leite et al. 2018). Ash produced from sugarcane trash burning can also adversely affect fish species living in the surrounding aquatic systems (Gonino et al. 2019).

\section{Response ( $R$ ) of long-term monoculture of sugarcane farming in Indonesia}

Response refers to the actions adopted by the relevant stakeholders, i.e., sugarcane growers, companies, and government to overcome environmental problems and yield decline in the sugarcane monoculture plantations in Indonesia (Table 1). The incorporation of ecological practices into sugarcane cultivation management can alleviate the adverse effects of monocropping on environmental degradation and yield decline. Land management measures should be directed to address the trade-off between economic development and greater biodiversity sustainability (Beza and Assen 2017). The Indonesian government can offer a set of policies and instruments related to the strategies, while initiatives from sugarcane growers are also important.

\section{Crop break or crop rotation with legume or other crops}

Breaking sugarcane monoculture by growing legumes or other plants in rotation can be beneficial for the environment and crop growth. Biomass from the plant in the rotation system can be used as a green fertilizer if incorporating into the soil. Crop break or rotation can improve soil fertility, primarily if legume is used (Park et al. 2010; Stirling et al. 2010). This practice can also help break the pests and pathogens cycle (Stirling et al. 2010), controlling root pathogens, leading to an increase of 11$30 \%$ of sugarcane yield (Ambrosano et al. 2013).

Although the use of green fertilizer by the sugarcane growers is uncommon, it is not a new practice in Indonesia. In the past, many sugarcane farmers used to plant breaking crops before sugarcane planting or after ratoon unloading. During the Dutch colonial era, sugarcane growers in Jombang and Kediri, East Java, often employed Crotalaria juncea as green fertilizer. However, with the growing practice of sugarcane monoculture, there is limited space and time to plant such green fertilizer. Sugarcane growers are currently more dependent on inorganic fertilizers (Djajadi 2015). Sugarcane growers may also become indolent in applying green fertilizer since they need to spend money on removal of sugarcane stumps, soil tillage, and planting (Srivastava and Rai 2012; Ambrosano et al. 2013). Besides, the positive impacts of crop break cannot be seen immediately. It took some time for nitrogen from legume to be mineralized and available for sugarcane in a legume-sugarcane rotation system (Park et al. 2010).

\section{Intercropping}

In sugarcane cultivation, intercropping can be done right after soil tillage or planting time up to three or four months following planting time. After this period, sugarcane canopy will grow larger, and sunlight cannot penetrate; thus, another crop cannot grow optimally under the shade. Intercropping of sugarcane with legume or other crops can improve soil structure and fertility ( $\mathrm{Li}$ et al. 2012). Yang et al. (2013) found that sugarcane intercropping with soybean improves land and nitrogen use efficiency compared to sugarcane monoculture. Several studies reported an increase of sugarcane yield in intercropping with soybean (Luo et al. 2016; Wang et al. 2020) because sugarcane gets additional nitrogen. Legumes 
can establish symbiosis with Rhizobium bacteria to fix nitrogen from the atmosphere. Intercropping can also help in improving soil microbial diversity ( $\mathrm{Li}$ et al. 2012; Solanki et al. 2019) and its activity (Solanki et al. 2019), increasing AMF (Zhang et al. 2020), as well as providing extra economic benefits to sugarcane growers (Chagas et al. 2015; Teshome et al. 2015; Ullah et al. 2017; Shukla et al. 2019; Nadeem et al. 2020).

Table 1. Summary of possible crop management modifications to mitigate the adverse impacts of sugarcane monoculture

\begin{tabular}{|c|c|c|}
\hline $\begin{array}{l}\text { Crop } \\
\text { management } \\
\text { options }\end{array}$ & Reported benefit(s) from previous worldwide studies & $\begin{array}{l}\text { Reported disadvantage(s) from } \\
\text { previous worldwide studies }\end{array}$ \\
\hline $\begin{array}{l}\text { Crop break or } \\
\text { crop rotation } \\
\text { with legume } \\
\text { or the other } \\
\text { crops }\end{array}$ & $\begin{array}{l}\text { - Fixing atmospheric nitrogen to the soil if legume is used; thus increasing } \\
\text { total N to the soil (Park et al. 2010; Stirling et al. 2010) } \\
\text { - Breaking pests and pathogens cycle (Stirling et al. 2010) } \\
\text { - Controlling root pathogens (Ambrosano et al. 2013) } \\
\text { - Enhancing sugarcane growth (Ambrosano et al. 2013) }\end{array}$ & $\begin{array}{l}\text { - Cash is needed to demolish } \\
\text { sugarcane stumps, soil tillage, and } \\
\text { planting (Srivastava and Rai 2012; } \\
\text { Ambrosano et al. 2013) } \\
\text { - The positive impacts cannot be } \\
\text { seen immediately (Park et al. 2010) }\end{array}$ \\
\hline Intercropping & $\begin{array}{l}\text { - Improving soil structure and fertility (Li et al. 2012) } \\
\text { - Improving land-use efficiency (Yang et al. 2013) } \\
\text { - Enhancing soil microbial diversity (Li et al. 2012; Solanki et al. 2019) } \\
\text { and activity (Solanki et al. 2019), as well as arbuscular mycorrhizal } \\
\text { fungi (AMF) (Zhang et al. 2020) } \\
\text { - Increasing sugarcane yield (Luo et al. 2016; Wang et al. 2020) } \\
\text { - Providing extra economic benefits to growers (Chagas et al. 2015; } \\
\text { Teshome et al. 2015; Kaur et al. 2016; Ullah et al. 2017; Shukla et al. } \\
\text { 2019; Singh 2020) }\end{array}$ & $\begin{array}{l}\text { - Potentially reducing sugarcane } \\
\text { yields due to competition between } \\
\text { sugarcane and the other crops } \\
\text { (Layek et al. 2015) }\end{array}$ \\
\hline $\begin{array}{l}\text { Green } \\
\text { harvesting and } \\
\text { trash blanket }\end{array}$ & $\begin{array}{l}\text { - Maintaining or improving soil organic carbon and the other nutrients } \\
\text { (Singh et al. 2012; Trivelin et al. 2013; Shukla et al. 2016; Sandhu et al. } \\
\text { 2017; Bordonal et al. 2018; Luca et al. 2018; Castioni et al. 2019) } \\
\text { - Improving soil physical quality attributes, such as increasing soil water- } \\
\text { stable aggregates (Surendran et al. 2016) and preventing soil compaction } \\
\text { (Castioni et al. 2018) } \\
\text { - Avoiding sudden fluctuations in soil temperature (Awe et al. 2015) } \\
\text { - Preserving soil moisture (Liao et al. 2013; Nxumalo et al. 2016; de } \\
\text { Aquino et al. 2017; Castioni et al. 2018; de Castro et al. 2018; Corrêa et } \\
\text { al. 2019) } \\
\text { - Increasing water use efficiency (Ng Cheong and Teeluck 2015; } \\
\text { Dhanapal et al. 2018) } \\
\text { - Reducing weed growth and costs for it (Tortora et al. 2013) } \\
\text { - Enhancing earthworm populations (Castioni et al. 2018) } \\
\text { - Increasing sugarcane yield (Surendran et al. 2016; Singh et al. 2012; } \\
\text { Liao et al. 2013; Ng Cheong and Teeluck 2015; Nxumalo et al. 2016; de } \\
\text { Aquino et al. 2017; de Aquino et al. 2018; Bordonal et al. 2018; } \\
\text { Dhanapal et al. 2018; Corrêa et al. 2019) } \\
\text { - Reducing GHG emissions if residues are not burned before or after } \\
\text { harvesting (Pryor et al. 2017) }\end{array}$ & $\begin{array}{l}\text { - Escalating risk of fire within } \\
\text { sugarcane plantations (de Castro et } \\
\text { al. 2018) } \\
\text { - Increasing pests and pathogens } \\
\text { proliferation (de Castro et al. 2018) } \\
\text { - Increasing GHG emissions (do } \\
\text { Carmo et al. 2012; Wang et al. } \\
\text { 2016) } \\
\text { - Higher labor costs if manual green } \\
\text { harvesting method is applied } \\
\text { (Junpen et al. 2020) }\end{array}$ \\
\hline $\begin{array}{l}\text { Precision } \\
\text { agriculture } \\
\text { (PA) }\end{array}$ & $\begin{array}{l}\text { - Lowering environmental impacts (Prasara-A and Gheewala 2016) } \\
\text { - Reducing input and production cost (Prasara-A and Gheewala 2016) } \\
\text { - Increasing sugarcane yield and quality (Silva et al. 2011) }\end{array}$ & $\begin{array}{l}\text { - High technology and services costs } \\
\text { (Silva et al. 2011; Pedersen and } \\
\text { Lind 2017) } \\
\text { - Adequate information and } \\
\text { knowledge to operate PA's } \\
\text { technologies are needed (Silva et } \\
\text { al. 2011; Pedersen and Lind 2017) }\end{array}$ \\
\hline $\begin{array}{l}\text { Organic } \\
\text { matter }(\mathrm{OM}) \\
\text { amendment }\end{array}$ & $\begin{array}{l}\text { - Many OM types can be used, including filter cake (by-product of sugar } \\
\text { mills) and vinasse (by-product of sugarcane-based bioethanol } \\
\text { distilleries) (Djajadi 2015; Dotaniya et al. 2016) } \\
\text { - Improving soil quality (chemical, physical, biological) (Jiang et al. 2012; } \\
\text { Prado et al. 2013; Dotaniya et al. 2016; dos Santos et al. 2020) } \\
\text { - Increasing the abundance of soil biota, including soil microbes (Balota } \\
\text { and Auler 2011; Nair and Ngouajio 2012; Neher et al. 2013; van Horn et } \\
\text { al. 2013; Zaccardelli et al. 2013; El-Sharouny 2014; Zhen et al. 2014; } \\
\text { Sun et al. 2015; Francioli et al. 2016; Spiegel et al. 2018; Zhu et al. } \\
\text { 2020) and fungi (Miura et al. 2013; Yang et al. 2018) } \\
\text { - Enhancing sugarcane yield and quality (Dotaniya et al. 2016) }\end{array}$ & $\begin{array}{l}\text { Some OM types such as untreated } \\
\text { filter cake or vinasse lead to } \\
\text { environmental pollution (Prado et } \\
\text { al. 2013), includes GHG emission } \\
\text { (do Carmo et al. 2012) }\end{array}$ \\
\hline
\end{tabular}


Although intercropping is beneficial, it can also potentially reduce sugarcane yield. Some preliminary studies discovered a lower yield of sugarcane grown in an intercropping system than monoculture, although the differences are insignificant (Layek et al. 2015; Ullah et al. 2017). This condition can be occurred due to competition for solar radiation, as well as nutrients and moisture in the soil between sugarcane and the other crops (Layek et al. 2015). Therefore, it is necessary to choose 'suitable' crops intercropped with sugarcane.

\section{Green harvesting and trash blanket}

Sugarcane plantations produce many residues (trashes) that can be potentially used as organic fertilizers. However, such potential has not been fully exploited by most Indonesian sugarcane growers.

Many growers prefer to burn sugarcane residues prior to harvesting to make the harvesting process easier, faster, and convenient. However, implementing the burning practice in sugarcane plantation means 'throwing away' organic matter from the plantation.

Sugarcane residues have an important role in sustaining soil functions (Castioni et al. 2018). By implementing green harvesting and trash blanket method, trashes or residual sugarcane biomasses are returned back to the plantation as fertilizer. Sugarcane residues are essential sources of carbon and other nutrients such as minerals hence it can maintain or even improve soil fertility (Singh et al. 2012; Trivelin et al. 2013; Shukla et al. 2016; Bordonal et al. 2018; Luca et al. 2018; Castioni et al. 2019). Trash blanket also increases the abundance of soildwelling organisms, such as earthworms (Castioni et al. 2018). An increased number of earthworms can help in regulating soil structure (Sharma et al. 2017; Frazão et al. 2019) and play a role in the soil nutrient cycling process through decomposition and mineralization (Lubbers et al. 2010; Bernard et al. 2012; Domínguez and GómezBrandón 2013; van Groenigen et al. 2014; Wachendorf et al. 2014; Waqar et al. 2019); thus, it leads to reduced fertilizer requirements. Previous studies showed an increase in sugarcane yield due to the implementation of trash blanket (Surendran et al. 2016; Singh et al. 2012; Liao et al. 2013; Ng Cheong and Teeluck 2015; Nxumalo et al. 2016; de Aquino et al. 2017; de Aquino et al. 2018; Bordonal et al. 2018; Dhanapal et al. 2018; Corrêa et al. 2019). If the trash blanket method is implemented continuously in a sugarcane plantation, beneficial soil biota will create a positive feedback system with continuous soil fertility improvements. In Lampung, Salamah et al. (2016) found a higher earthworm population in sugarcane plantation under organic mulching treatments than that of non-mulching treatments. However, the magnitude of the positive impacts of trash blanket implementation depends on the amounts of residues, climate, and soil types in the plantation, as well as crop management (Castioni et al. 2018). Carvalho et al. (2017) suggested that the positive impacts of implementing a trash blanket are attained when at least seven tons per hectares of trashes are maintained on the soil surface.
To implement the trash blanket, sugarcane residues should firstly be cut into small pieces. It can be done manually or mechanically by using a rotary mulcher and trash shredder. Then, the cut residues are used as soil cover over the plantations. This can be done manually or mechanically using hay rake and wheel trash rake (Nalawade et al. 2018).

Although there are numerous benefits of implementing a trash blanket, there are also some drawbacks of applying trash blankets, such as the increased risk of fire and higher proliferation of sugarcane pests and pathogens (de Castro et al. 2018). If manual harvesting without prior burning is performed, a higher labor cost is also needed (Junpen et al. 2020). Even so, these costs can be possibly compensated by reduced fertilizer costs and increased sugarcane productivity in the long run.

\section{Precision agriculture (PA)}

Precision agriculture (PA) allows growers to irrigate and fertilize their crops using a precise amount of water and fertilizers at the right time, in accordance with the actual field condition (Shafi et al. 2019). The use of optimal quantities of fertilizers and pesticides in PA can lower the environmental impacts and lessens production costs without compromising the sugarcane yields (Silva et al. 2011; Prasara-A and Gheewala 2016). PA can also minimize eutrophication effects on water bodies near sugarcane plantations. Furthermore, this method can contribute to the agricultural water use efficiency to maintain the hydrological functions. Among the examples of PA technologies applicable for sugarcane plantation are automatic planters or harvesters, satellite images, aerial photography, georeferenced soil sampling, satellite steering system, weed, and disease sensors, as well as soil electrical conductivity sampling (Silva et al. 2011).

Although PA offers some benefits to sugarcane growers, relatively higher investment is required to purchase PA-related technologies as well as for their maintenance. Besides, adequate knowledge on how to operate the PA's technologies is needed (Silva et al. 2011; Pedersen and Lind 2017). PA relies on the collection, analysis, processing, and synthesis of comprehensive georeferenced data (Driemeier et al. 2016). This can become a barrier for Indonesian sugarcane growers, especially smallholders, who do not even have access to the basic information regarding the technology. However, PA can still be possibly performed by large Indonesian sugarcane companies, such as private companies and PTPN, since they often have adequate capital and human resources.

\section{Organic matter (OM) amendment}

By far in Indonesia, OM is rarely amended into sugarcane plantations since growers prefer to use inorganic fertilizers. For instance, some of PTPN have applied filter cake and the other types of OM to their sugarcane plantations. However, the application is limited to a small scale and not fairly distributed throughout the estates. In general, Indonesian sugarcane growers may not prefer the 
soil amendment with OM since the positive effects of the $\mathrm{OM}$ cannot be seen immediately. Sugarcane growers in Kediri and Jombang, East Java, experienced that their sugarcane-cultivated soil becomes harder, and additional urea is needed due to the OM amendment. However, this might be a short-term effect as the chemical, biological, and physical aspects of soil are reported to be improved in the long-term OM application (Djajadi 2015).

Previous studies reported an increase in the abundance of soil organisms, including soil microbes due to OM amendments (Balota and Auler 2011; Nair and Ngouajio 2012; Neher et al. 2013; van Horn et al. 2013; Zaccardelli et al. 2013; El-Sharouny 2014; Zhen et al. 2014; Sun et al. 2015; Francioli et al. 2016; Spiegel et al. 2018; Zhu et al. 2020) and fungi (Miura et al. 2013; Yang et al. 2018). Consequently, these microbes contribute to nutrient cycling processes and aggregate formation (Rashid et al. 2016). Several beneficial soil biotas, such as bacteria and fungi, are categorized as plant-growth-promoting microbes (PGPM). These microorganisms can enhance plant growth performance. PGPM can regulate plant hormones, produce siderophore, improve the antioxidant system, and increase nutrient acquisition in plants (Kumar and Verma 2018). They can also induce resistance of sugarcane against pests and pathogens as well as several abiotic stresses, such as soil salinity and drought (Naik et al. 2019).

Several types of OM can be used as soil amendments in sugarcane plantation, such as green composts, manure, biofertilizers, or a combination of them (Djajadi 2015). Byproducts produced from sugar mills and sugarcane-based bioethanol distilleries such as filter cake, bagasse, and vinasse can also be used as OM. However, such byproducts should be firstly treated or composted before used; or otherwise, it can cause environmental pollution. Raw filter cake or vinasse has a low $\mathrm{pH}$, high biological oxygen demand (BOD), and high chemical oxygen demand (COD) (Prado et al. 2013). Besides, similar to inorganic fertilizer, some OM types such as manure, filter cake, and vinasse might also potentially emit GHG emissions (do Carmo et al. 2012). Furthermore, it should be taken into account the proper dosage and timing of application to minimize the emissions.

Indonesian sugarcane growers are suggested to implement one or a combination of several management options mentioned before (Table 1); hence, achieving both environmental and economic sustainability is possible. The growers should decide which practice fits best for their plantation since each crop management has drawbacks. Besides the five aforementioned crop managements, many researchers also suggest a minimum or zero tillage conserve soils under monoculture (Palm et al. 2014). Nevertheless, the implementation of this method is nearly impossible to be implemented in the Indonesian sugarcane plantations due to the rooted habit of extensive soil tillage among sugarcane growers, unless there is an adequate knowledge amongst the growers regarding the benefits of zero-tillage implementation.

The present study only emphasizes on the environmental impacts of the sugarcane monoculture in
Indonesia. Other than that, there are also some positive impacts of the system on socio-economic factors that are not included in the DPSIR framework. For instance, monocultures may create job opportunities. This is because generally, the sugar production process, from sugarcane cultivation to processing in the sugar mill, often requires high labors. Besides, the sugarcane monoculture system also supports the continuity of sugarcane supply for sugar mills in Indonesia.

To conclude, a conventional monoculture is still practiced by sugarcane growers in Indonesia, especially by large sugar companies. Smallholder growers are more flexible since they may change their crops to other commodities that are more profitable. However, most of them still preserve their sugarcane plantations due to farming practicality, lower production cost, and an expectation to profit in subsequent harvests. It is obvious that the main underlying drivers are population factors and the rise in sugar demand over time. On one side, it helps to fulfill domestic sugar demand in Indonesia. Notwithstanding, the conventional method of sugarcane cultivation in long-term duration contributes to decreased soil quality and some environmental problems, leading to reduced productivity of sugarcane. Since it is difficult to make such a trade-off between sugar production and environment, sustainable sugarcane cultivation management can serve a win-win solution, i.e., crop break or crop rotation, intercropping, green harvesting and trash blanketing, and PA. Each of them has advantages and disadvantages, so sugarcane growers must consider which management practice best fits their plantation.

\section{ACKNOWLEDGEMENTS}

We would like to thank ISRI for the support given to convey this study. No potential conflict of interest was declared by all the authors.

\section{REFERENCES}

Altieri MA, Nicholls CI, Henao A, Lana MA. 2015. Agroecology and the design of climate change-resilient farming systems. Agron Sust Dev 35: 869-890. DOI: 10.1007/s13593-015-0285-2.

Ambrosano EJ, Cantarella H, Ambrosano GMB, Dias FLF, Rossi F, Trivelin PCO, Muraoka T. 2013. The role of green manure nitrogen use by corn and sugarcane crops in Brazil. Agric Sci 4 (12): 89-108. DOI: 10.4236/as.2013.412A008.

Awe GO, Reichert JM, Wendroth OO. 2015. Temporal variability and covariance structures of soil temperature in a sugarcane field under different management practices in southern Brazil. Soil Tillage Res 150: 93-106. DOI: 10.1016/j.still.2015.01.013.

Balota EL, Auler PAM. 2011. Soil microbial biomass under different management and tillage systems of permanent intercropped cover species in an orange orchard. Rev Bras Ciênc Solo 35 (6): 1873-1883. DOI: 10.1590/S0100-06832011000600004.

Bernard L, Chapuis-Lardy L, Razafimbelo T, Razafindrakoto M, Pablo A, Legname E, Poulain J, Brüls T, O’Donohue M, Brauman A, Chotte J, Blanchart E. 2012. Endogeic earthworms shape bacterial functional communities and affect organic matter mineralization in a tropical soil. ISME J 6: 213-222. DOI: 10.1038/ismej.2011.87. 
Beza SA, Assen MA. 2017. Expansion of sugarcane monoculture: associated impacts and management measures in the semi-arid East African Rift Valley, Ethiopia. Environ Monit Assess 189: 1-14. DOI: 10.1007/s10661-016-5761-x.

Bordonal RO, Lal R, Ronquim CC, de Figueiredo EB, Carvalho JLN, Maldonado Jr. W, Milori DMBP, Scala Jr. NL. 2017. Changes in quantity and quality of soil carbon due to the land-use conversion to sugarcane (Saccharum officinarum L.) plantation in southern Brazil. Agric Ecosyst Environ 240: 54-65. DOI: 10.1016/j.agee.2017.02.016.

Bordonal RO, Menandro LMS, Barbosa LC, Lal R, Milori DMBP, Kolln OT, Franco HCJ, Carvalho JLN. 2018. Sugarcane yield and soil carbon response to straw removal in south-central Brazil. Geoderma 328: 79-90. DOI: 10.1016/j.geoderma.2018.05.003.

Budianto EE. 2018. Ungkap pencemaran sumur warga, ini yang dilakukan DLH Mojokerto. Detik News. https://news.detik.com/berita-jawatimur/d-4308682/ungkap-pencemaran-sumur-warga-ini-yangdilakukan-dlh--mojokerto. [Indonesian]

Brown to Green report. 2017. Climate Transparency: The G20 transition to a low-carbon economy.

Carvalho JL, Nogueirol RC, Menandro LMS, Bordonal RO, Borges CD, Cantarella H, Franco HCJ. 2017. Agronomic and environmental implications of sugarcane straw removal: a major review. GCB Bioenergy 9: 1181-1195. DOI: 10.1111/gcbb.12410.

Castioni GA, Cherubin MR, Menandro LMS, Sanches GM, Bordonal RO, Barbosa LC, Franco HCJ, Carvalho JLN. 2018. Soil physical quality response to sugarcane straw removal in Brazil: A multi-approach assessment. Soil Tillage Res 184: 301-309. DOI: 10.1016/j.still.2018.08.007.

Castioni GA, Cherubin MR, Bordonal RO, Barbosa LC, Menandro LMS, Carvalho JLN. 2019. Straw removal affects soil physical quality and sugarcane yield in Brazil. BioEnergy Res 12 (4): 789-800. DOI: 10.1007/s12155-019-10000-1.

Cavalcanti RQ, Rolim MM, de Lima RP, Tavares UE, Pedrosa EMR, Cherubin MR. 2020. Soil physical changes induced by sugarcane cultivation in the Atlantic Forest biome, northeastern Brazil. Geoderma 370: 114353. DOI: 10.1016/j.geoderma.2020.114353.

Chagas MF, Bordonal RO, Cavalett O, Carvalho JLN, Bonomi A, Jr NLS. 2015. Environmental and economic impacts of different sugarcane production systems in the ethanol biorefinery. Biofuels Bioproducts Biorefining 10 (1): 89-106. DOI: 10.1002/bbb.1623.

Chi L, Mendoza-Vega J, Huerta E, Alvarez-Solis JD. 2017. Effect of longterm sugarcane (Saccharum spp.) cultivation on chemical and physical properties of soils in Belize. Commun Soil Sci Plant Anal 48 (7): 741-755. DOI: 10.1080/00103624.2016.1254794.

Corrêa STR, Barbosa LC, Menandro LMS, Scarpare FV, Reichardt K, De Moraes LO, Hernandes TAD, Franco HCJ, Carvalho JLN. 2019. Straw removal effects on soil water dynamics, soil temperature, and sugarcane yield in South-Central Brazil. BioEnergy Res 12 (4): 749 763. DOI: 10.1007/s12155-019-09981-w.

Cristale J, Silva FS, Zocolo GJ, Marchi MRR. 2012. Influence of sugarcane burning on indoor/outdoor PAH air pollution in Brazil. Environ Pollut 169: 210-216. DOI: 10.1016/j.envpol.2012.03.045

Davis AM, Thorburn PJ, Lewis SE, Bainbridge ZT, Attard SJ, Milla R, Brodie JE. 2011. Environmental impacts of irrigated sugarcane production: Herbicide run-off dynamics from farms and associated drainage systems. Agric Ecosyst Environ 180: 123-135. DOI: 10.1016/j.agee.2011.06.019.

de Aquino GS, Medina CC, Da Costa DC, Shahab M, Santiago AD. 2017. Sugarcane straw management and its impact on production and development of ratoons. Ind. Crops Prod. 102: 58-64. DOI: 10.1016/j.indcrop.2017.03.018

de Aquino GS, Medina CC, Shahab M, Santiago AD, Cunha ACB, Kussaba DAO, Carvalho JB, Moreira A. 2018. Does straw mulch partial-removal from soil interfere in yield and industrial quality sugarcane? A long term study. Ind. Crops Prod. 111: 573-578. DOI: 10.1016/j.indcrop.2017.11.026

de Castro SGQ, Magalhães PSG, Franco HCJ, Mutton MÂ. 2018 Harvesting systems, soil cultivation, and nitrogen rate associated with sugarcane yield. BioEnergy Res 11 (3): 583-591. DOI: 10.1007/s12155-018-9917-0.

de Figueiredo EB, Panosso AR, Romão R, La Scala N. 2010. Greenhouse gas emission associated with sugar production in southern Brazil. Carbon Balance Manag 5 (1): 1-7. DOI: 10.1186/1750-0680-5-3.
Dhanapal R, Tayade AS, Bhaskaran A, Geetha P. 2018. Efficient water management in sugarcane with composted coir pith and sugarcane trash under tropical Indian conditions. Sugar Tech 21 (2): 256-264. DOI: $10.1007 / \mathrm{s} 12355-018-0593-3$.

Directorate General of Estate Crops (Direktorat Jenderal Perkebunan RI). 2016. Tree crop estate Statistics of Indonesia 2015-2017 (Statistik Perkebunan Indonesia 2015-2017). drive.google.com/file/d/1 AImRSsPkpx8SPZreMUYpIjWIT4fKtiz/view. [Indonesian]

do Carmo JB, Filoso S, Zotelli L, Neto ES. 2012. Infield greenhouse gas emissions from sugarcane soils in Brazil: Effects from synthetic and organic fertilizer application and crop trash accumulation. GCB Bioenergy 5 (3): 267-280. DOI: 10.1111/j.1757-1707.2012.01199.x.

Domínguez J, Gómez-Brandón M. 2013. The influence of earthworms on nutrient dynamics during the process of vermicomposting. Waste Manag Res 31 (8): 859-868. DOI: 10.1177/0734242X13497079.

dos Santos OAQ, Tavares OCH, Garcia AC, Rossi CQ, de Moura OVT, Pereira W, Pinto LASR, Berbara RLL, Pereira MG. 2020. Fire lead to disturbance on organic carbon under sugarcane cultivation but is recovered by amendment with vinasse. Sci Tot Environ 739: 140063. DOI: $10.1016 /$ j.scitotenv.2020.140063.

Dotaniya ML, Datta SC, Biswas DR, Dotaniya CK, Meena BL, Rajendiran S, Regar KL, Lata M. 2016. Use of sugarcane industrial by-products for improving sugarcane productivity and soil health. Int J Recycl Org Waste Agric 5 (3): 185-194. DOI: 10.1007/s40093-0160132-8.

Djajadi. 2015. Bahan organik: peranannya dalam budidaya tebu berkelanjutan. Perspektif 14: 61-71. DOI: 10.21082/p.v14n1.2015.6171. [Indonesian]

Driemeier C, Ling LY, Sanches GM, Pontes AO, Magalhães PSG, Ferreira JE. 2016. A computational environment to support research in sugarcane agriculture. Comp Electronics in Agric 130: 13-19. DOI: 10.1016/j.compag.2016.10.002.

El-Sharouny EE. 2014. Effect of different soil amendments on the microbial count correlated with resistance of apple plants towards pathogenic Rhizoctonia solani AG-5. Biotech Biotechnol Equipment 29 (3): 463-469. DOI: 10.1080/13102818.2014.1002285.

FAO (Food and Agriculture Organization of the United Nations). 2018. Statistics for sugarcane production in Indonesia and the world. www.fao.org/faostat/en/\#data/QC.

FAOSTAT. 2020

Sugar cane. data.un. org/Data.aspx?d=FAO\& $\mathrm{f}=$ itemCode $\% 3 \mathrm{a} 156$

Francioli D, Schulz E, Lentendu G, Wubet T, Buscot F, Reitz T. 2016. Mineral vs organic amendments: Microbial community structure, activity and abundance of agriculturally relevant microbes are driven by long-term fertilization strategies. Front Microbiol 7: 1446. DOI: 10.3389/fmicb.2016.01446.

Frazão J, de Goede RGM, Capowiez Y, Pulleman MM. 2019. Soil structure formation and organic matter distribution as affected by earthworm species interactions and crop residue placement. Geoderma 338: 453-463. DOI: 10.1016/j.geoderma.2018.07.033.

Galdos MV, Cerri CC, Lal R, BernouxM, Feigl B, Cerris CEP. 2010. Net greenhouse gas fluxes in Brazilian ethanol production systems. GCB Bioenergy 2 (1): 37-44. DOI: 10.1111/j.1757-1707.2010.01037.x.

German LA, Hepinstall-Cymerman J, Biggs T, Parker L, Salinas M. 2020. The environmental effects of sugarcane expansion: a case study of changes in land and water use in southern Africa. Appl Geogr 121: 102240. DOI: $10.1016 /$ j.apgeog.2020.102240.

Gonino GMR, Figueiredo BRS, Manetta GI, Alves GHZ, Benedito E. 2019. Fire increases the productivity of sugarcane, but it also generates ashes that negatively affect native fish species in aquatic systems. Sci Tot Environ 664: 215-221. DOI: 10.1016/j.scitotenv.2019.02.022.

Hawkins IW (ed.). 2018. Promoting Biodiversity in Food Systems. CRC Press. DOI: 10.1201/b22084.

Hervani A, Kartikawati R, Ariani M, Setyanto P. 2017. $\mathrm{N}_{2} \mathrm{O}$ emissions from rainfed sugarcane plantation. Buletin Tanaman Tembakau, Serat \& Minyak Industri 9: 10-14. DOI: 10.21082/btsm.v9n1.2017.10-14. [Indonesian]

Hess TM, Sumberg J, Biggs T, Georgescu M, Haro-Monteagudo D, Jewitt G, Ozdogan M, Marshall M, Thenkabail P, Daccache A, Marin F, Knox JW. 2016. A sweet deal? Sugarcane, water and agricultural transformation in Sub-Saharan Africa. Glob Environ Change 39: 181194. DOI: 10.1016/j.gloenvcha.2016.05.003. 
Hester RE, Harrison RM (eds). 2007. Biodiversity Under Threat (Vol. 25). Royal Society of Chemistry, London. DOI: 10.1039/978184755765000263.

Idris M. 2016. Meski sering rugi, kenapa petani masih tanam tebu? Detik Finance. https://finance.detik.com/industri/d-3215502/meski-seringrugi-kenapa-petani-masih-tanam-tebu. [Indonesian]

Indonesian Ministry of Agriculture. 2020. Produktivitas tebu menurut provinsi, 2020.www.pertanian.go.id/home/?show=page \&act=view \&id=61. [Indonesian]

ISRI [Indonesian Sugar Research Institute]. 2004. Annual Report 2004. [Indonesian]

Ivansyah. 2015. Hutan menghilang, warga gugat pabrik gula. Tempo. https://nasional.tempo.co/read/667571/hutan-menghilang-wargagugat-pabrik-gula. [Indonesian]

Jiang ZP, Li YR, Wei G, Liao Q, Su T, Meng Y, Zhang H, Lu C. 2012. Effect of long-term vinasse application on physicochemical properties of sugarcane field soils. Sugar Tech 14: 412-417. DOI: 10.1007/s12355-012-0174-9.

Junpen A, Pansuk J, Garivait S. 2020. Estimation of reduced air emissions as a result of the implementation of the measure to reduce burned sugarcane in Thailand. Atmosphere 11 (4): 366. DOI: 10.3390/atmos11040366

Kaur N, Bhullar MS, Gill G. 2016. Weed management in sugarcanecanola intercropping systems in northern India. Field Crops Res 188 1-9. DOI: $10.1016 /$ j.fcr.2016.01.009.

Kumar A, Verma JP. 2018. Does plant-microbe interaction confer stress tolerance in plants: A review. Microb Res 207: 41-52. DOI: 10.1016/j.micres.2017.11.004

Kusumawati A, Hanudin E, Purwanto BH, Nurudin M. 2020 Composition of organic $\mathrm{C}$ fractions in soils of different texture affected by sugarcane monoculture. Soil Sci Plant Nutr 66: 206-213. DOI: $10.1080 / 00380768.2019 .1705740$.

Layek J, Shivakumar BG, Rana DS, Munda S, Lakshman K, Panwar AS, Das A, Ramkhrusna GI. 2015. Performance of soybean (Glycine max) intercropped with different cereals under varying levels of nitrogen. Indian J Agric Sci 85 (12): 1571-1577. DOI: 10.2134/agronj13.0521.

Le Blond JS, Woskie S, Horwell CJ, Williamson BJ. 2017. Particulate matter produced during commercial sugarcane harvesting and processing: a respiratory health hazard? Atmos Environ 149: 34-46. DOI: $10.1016 / j$.atmosenv 2016.11.012.

Leite MR, Zanetta DMT, Trevisan IB, Burdmann EA, Santos UP. 2018 Sugarcane cutting work, risks, and health effects: a literature review. Rev Saúde Pública 52: 1-15. DOI: 10.11606/S15188787.2018052000138

Li X, Mu Y, Cheng Y, Liu X, Nian H. 2012. Effects of intercropping sugarcane and soybean on growth, rhizosphere soil microbes, nitrogen and phosphorus availability. Acta Physiol Plant 35 (4): 1113-1119. DOI: $10.1007 / \mathrm{s} 11738-012-1148-y$.

Liao Q, Wei G, Chen G, Liu B, Huang D, Li Y. 2013. Effect of trash addition to the soil on microbial communities and physico-chemical properties of soils and growth of sugarcane plants. Sugar Tech 16 (4): 400-404. DOI: 10.1007/s12355-013-0296-8.

Lubbers IM, Brussaard L, van Groenigen JW. 2010. Earthworm-induced $\mathrm{N}$ mineralization in fertilized grassland increases both $\mathrm{N}_{2} \mathrm{O}$ emission and crop-N uptake. Eur. J Soil Sci 62 (1): 152-161. DOI 10.1111/j.1365-2389.2010.01313.x

Luca EF, Chaplot V, Mutema M, Feller C, Ferreira ML, Cerri CC, Couto HTZ. 2018. Effect of conversion from sugarcane preharvest burning to residues green-trashing on SOC stocks and soil fertility status: Results from different soil conditions in Brazil. Geoderma 310: 238248. DOI: 10.1016/j.geoderma.2017.09.020.

Luo S, Yu L, Liu Y, Zhang Y, Yang W, Li Z, Wang J. 2016. Effects of reduced nitrogen input on productivity and $\mathrm{N}_{2} \mathrm{O}$ emissions in a sugarcane/soybean intercropping system. Eur J Agron 81: 78-85. DOI: 10.1016/j.eja.2016.09.002.

Maxim L, Spangenberg JH, O’Connor M. 2009. An analysis of risks for biodiversity under the DPSIR framework. Ecol Econ 69: 12-23. DOI: 10.1016/j.ecolecon.2009.03.017.

Medina-Sauza RM, Álvarez-Jiménez M, Delhal A, Reverchon F, Blouin M, Guerrero-Analco J, Cerdán RC, Guevara R, Villain L, Barois I. 2019. Earthworms building up soil microbiota, a review. Front Environ Sci 7 (81): 1-20. DOI: 10.3389/fenvs.2019.00081.
Miura T, Niswati A, Swibawa IG, Haryani S, Gunito H, Kaneko N. 2013. No tillage and bagasse mulching alter fungal biomass and community structure during decomposition of sugarcane leaf litter in Lampung Province, Sumatra, Indonesia. Soil Bio Biochem 58: 27-35. DOI: 10.1016/j.soilbio.2012.10.042.

Mnatzaganian CL, Pellegrin KL, Miyamura J, Valencia D, Pang L. 2015. Association between sugar cane burning and acute respiratory illness on the island of Maui. Environ Health 14 (1): 1-8. DOI: 10.1186/s12940-015-0067-y.

Mwavu EN, Ariango E, Segawa P, Kalema VN, Bateganya F, Waiswa D, Byakagaba P. 2016. Agrobiodiversity of homegardens in a commercial sugarcane cultivation land matrix in Uganda. Int $\mathbf{J}$ Biodivers Sci Ecosyst Serv Manag 12 (3): 191-201.DOI: 10.1080/21513732.2016.1177595

Nadeem M, Tanveer A, Sandhu H, Javed S, Safdar ME, Ibrahim M, Shabir MA, Sarwar M, Arshad U. 2020. Agronomic and economic evaluation of autumn planted sugarcane under different planting patterns with lentil intercropping. Agronomy 10 (5): 1-24. DOI: 10.3390/agronomy10050644.

Naik K, Mishra S, Srichandan H, Singh PK, Sarangi PK. 2019. Plant growth-promoting microbes: Potential link to sustainable agriculture and environment. Biocatalysis Agric Biotech 21: 101326. DOI: 10.1016/j.bcab.2019.101326.

Nair A, Ngouajio M. 2012. Soil microbial biomass, functional microbial diversity, and nematode structure as affected by cover crops and compost in an organic vegetable production system. Appl Soil Ecol 58: 45-55. DOI: 10.1016/j.apsoil.2012.03.008

Nalawade S, Mehta AK, Sharma AK. 2018. Sugarcane planting techniques: A review. In: Contemporary research in India: National Seminar Recent Trends in Plant Sciences and Agricultural Research (PSAR-2018) (pp. 98-104).

Neher DA, Weicht TR, Bates ST, Leff JW, Fierer N. 2013. Changes in bacterial and fungal communities across compost recipes, preparation methods, and composting times. PLoS One 8 (11): e79512. DOI: 10.1371/journal.pone.0079512.

Netondo GW, Waswa F, Maina L, Naisiko T, Masayi N, Ngaira JK. 2010. Agrobiodiversity endangered by sugarcane farming in Mumias and Nzoia Sugarbelts of Western Kenya. Afr J Environ Sci Technol 4 (7): 437-445.

Ng Cheong LR, Teeluck M. 2015. The practice of green cane trash blanketing in the irrigated zone of Mauritius: effects on soil moisture and water use efficiency of sugarcane. Sugar Tech 18 (2): 124-133. DOI: $10.1007 / \mathrm{s} 12355-015-0374-1$

Nurhidayati AE, Suprayogo D, Hairiah K. 2011. Long-term impact of conventional soil management to earthworm diversity and density on sugarcane plantation in East Java, Indonesia. J Nat Stud 10 (2): 16-25.

NSC (Nusantara Sugar Community). 2020. Jurnal Gula. Nusantara Sugar Community, Jakarta, Indonesia. [Indonesian]

Nxumalo N, Ramburan S, Steyn JM. 2016. Growth and yield responses of commercial sugarcane cultivars to mulching in the coastal rainfed region of South Africa. S African J Plant Soil 34 (1): 9-18. DOI: 10.1080/02571862.2016.1148787

Our World in Data. 2020. Sugar cane production, 2018. ourworldindata.org/grapher/sugar-cane-production.

Palm C, Blanco-Canqui H, DeClerck F, Gatere L, Grace P. 2014. Conservation agriculture and ecosystem services: An overview. Agric Ecosyst Environ 187: 87-105. DOI: 10.1016/j.agee.2013.10.010.

Paraiso MLS, Gouveia N. 2015. Health risk due to pre-harvesting sugarcane burning in São Paulo State, Brazil. Rev Bras Epidemiol 18 (3): 691-701. DOI: 10.1590/1980-5497201500030014

Park SE, Webster TJ, Horan HL, James AT, Thorburn PJ. 2010. A legume rotation crop lessens the need for nitrogen fertiliser throughout the sugarcane cropping cycle. Field Crops Res 119(2-3): 331-341. DOI: 10.1016/j.fcr.2010.08.001

Pawirosemadi M. 2011. Dasar-Dasar Teknologi Budidaya Tebu dan Pengolahan Hasilnya. Universitas Negeri Malang Press, Malang. [Indonesian]

Pedersen SM, Lind KM (eds). 2017. Precision Agriculture: Technology and Economic Perspectives. Springer International Publishing. DOI: 10.1007/978-3-319-68715-5.

Pinheiro ÉFM, Lima E, Ceddia MB, Urquiaga S, Alves BJ, Boddey RM 2010. Impact of pre-harvest burning versus trash conservation on soil carbon and nitrogen stocks on a sugarcane plantation in the Brazilian 
Atlantic forest region. Plant Soil 333: 71-80. DOI:10.1007/s11104010-0320-7.

Pongpat P, Gheewala SH, Silalertruksa T. 2017. An assessment of harvesting practices of sugarcane in the central region of Thailand. J Cleaner Product 142: 1138-1147. DOI: 10.1016/j.jclepro.2016.07.178

Prado RDM, Caione G, Campos CNS. 2013. Filter cake and vinasse as fertilizers contributing to conservation agriculture. Appl Environ Soil Sci 2013: 1-8. DOI: 10.1155/2013/581984

Prasara-A J, Gheewala SH. 2016. Sustainability of sugarcane cultivation: case study of selected sites in north-eastern Thailand. J Cleaner Prod 134: 613-622. DOI: 10.1016/j.jclepro.2015.09.029.

Premono ME, Simoen S, Widayati WE, Ismail I, Sumoyo, Dardak A, Darmawan T, Yuschal, Windiharto, Prihatyo SH, Sudariyanto A. 1999. Daya Dukung Kesuburan Kesuburan Tanah dan Pemupukan di Unit Usaha Bungamayang dan Cintamanis. PT Perkebunan Nusantara VII dan Pusat Penelitian Perkebunan Gula Indonesia, Pasuruan. [Indonesian]

Pryor SW, Smithers J, Lyne P, Van Antwerpen R. 2017. Impact of agricultural practices on energy use and greenhouse gas emissions for South African sugarcane production. J Cleaner Production 141: 137 145. DOI: $10.1016 /$ j.jclepro.2016.09.069.

$\mathrm{Pu}$ W. 2015. Current situation and development trend of the sugarcane industry in Indonesia. Asian Agric Res 7: 32-34. DOI: 10.22004/ag.econ.210749.

Purwaningsih IW. 2016. Penilaian Daur Hidup (Life Cycle Assessment) Gula Tebu di PG Subang, Jawa Barat. [Thesis]. IPB University, Bogor. [Indonesian].

Ranomahera MRR, Ritzema H. 2020. Seeking alternatives of water-saving irrigation: Sprinkler irrigation for smallholder sugarcane farmers in East Java, Indonesia. IOP Conf. Ser.: Earth Environ. Sci. 437012033. DOI: $10.1088 / 1755-1315 / 437 / 1 / 012033$.

Rapport D, Friend A. 1979. Towards a Comprehensive Framework for Environmental Statistics: A Stress-Response Approach. Statistics Canada Catalogue 11-510. Minister of Supply and Services Canada, Ottawa.

Rashid MI, Mujawar LH, Shahzad T, Almeelbi T, Ismail IMI, Oves M. 2016. Bacteria and fungi can contribute to nutrients bioavailability and aggregate formation in degraded soils. Microbial Res 183: 26-41. DOI: 10.1016/j.micres.2015.11.007.

Renouf MA, Wegener MK, Pagan RJ. 2010. Life cycle assessment of Australian sugarcane production with a focus on sugarcane growing Int J Life Cycle Assess 15: 927-937. DOI: 10.1007/s11367-010-0226-

Salamah MH, Niswati A, Yusnaini S. 2016. Pengaruh sistem olah tanah dan pemberian mulsabagas terhadap populasi dan biomassa cacing tanah pada lahan pertanaman tebu tahun ke-5. Jurnal Agrotek Tropika 4: 222-227. DOI: 10.23960/jat.v4i3.1856. [Indonesian]

Sandhu HS, Singh MP, Gilbert R, Subiros-Ruiz F, Rice RW, Shine Jr JM. 2017. Harvest management effects on sugarcane growth, yield and nutrient cycling in Florida and Costa Rica. Field Crops Res 214: 253 260. DOI: $10.1016 /$ j.fcr.2017.09.002

Savario CF, Hoy JW. 2011. Microbial communities in sugarcane field soils with and without a sugarcane cropping history. Plant Soil 341 (1-2): 63-73. DOI: 10.1007/s11104-010-0622-9.

Shafi U, Mumtaz R, García-Nieto J, Hassan SA, Zaidi SAR, Iqbal N. 2019. Precision agriculture techniques and practices: from considerations to applications. Sensors 19 (17): 1-25. DOI: 10.3390/s19173796

Sharma A, Chandra A. 2017. Identification of new Leuconostoc species responsible for post-harvest sucrose losses in sugarcane. Sugar Tech 20 (4): 492-496. DOI: 10.1007/s12355-017-0562-2.

Sharma DK, Tomar S, Chakraborty D. 2017. Role of earthworm in improving soil structure and functioning. Curr Sci 113: 1064-1071. DOI: $10.18520 / \mathrm{cs} / \mathrm{v} 113 / \mathrm{i} 06 / 1064-1071$

Shukla SK, Shee S, Maity SK, Solomon S, Awasthi SK, Gaur A, Pathak AD, Jaiswal VP. 2016. Soil carbon sequestration and crop yields in rice-wheat and sugarcane-ratoon-wheat cropping systems through crop residue management and inoculation of Trichoderma viride in subtropical India. Sugar Tech 19 (4): 347-358. DOI: 10.1007/s12355016-0470-x.s.

Shukla SK, Solomon S, Sharma L, Jaiswal VP, Pathak AD, Singh P. 2019. Green technologies for improving cane sugar productivity and sustaining soil fertility in sugarcane-based cropping system. Sugar Tech 21 (2): 186-196. DOI: 10.1007/s12355-019-00706-z.

Silalertruksa T, Gheewala SH. 2018. Land-water-energy nexus of sugarcane production in Thailand. J Cleaner Prod 182: 521-528. DOI:10.1016/j.jclepro.2018.02.085.

Silva CB, de Moraes MAFD, Molin JP. 2011. Adoption and use of precision agriculture technologies in the sugarcane industry of Sāo Paulo state, Brazil. Precision Agric 12: 67-81. DOI: 10.1007/s11119009-9155-8.

Singh SN, Singh AK, Malik JPS, Kumar R, Sunderpal, Sharma ML. 2012. Cultural-practice packages and trash management effects on sugarcane ratoons under sub-tropical climatic conditions of India. J Agric Sci 150: 237-247. DOI: 10.1017/S0021859611000499.

Singh A. 2020. Benefits of crop diversification in Fiji's sugarcane farming. Asia Pacific Policy Stud 7 (1): 65-80. DOI: 10.1002/app5.291.

Solanki MK, Wang F, Li C, Wang Z, Lan T, Singh RK, Singh P, Yang L, Li Y. 2019. Impact of sugarcane-legume intercropping on diazotrophic microbiome. Sugar Tech 22 (1): 52-64. DOI: 10.1007/s12355-019-00755-4

Solomon S, Swapna M, Xuan VT, Mon YY. 2016. Development of sugar industry in ASEAN countries. Sugar Tech 18 (6): 559-575. DOI: 10.1007/s12355-016-0497-z.

Spiegel H, Mosleitner T, Sandén T, Zaller JG. 2018. Effects of two decades of organic and mineral fertilization of arable crops on earthworms and standardized litter decomposition. J Land Manag Food Environ 69 (1): 17-28. DOI: 10.2478/boku-2018-0003.

Srivastava AK, Rai MK. 2012. Review: Sugarcane production: Impact of climate change and its mitigation. Biodiversitas 13: 214-227. DOI:10.13057/biodiv/d130407.

Statistics Indonesia (Badan Pusat Statistik). 2018. Indonesian Sugar Cane Statistics 2018. [Indonesian]

Steduto P, Hsiao TC, Fereres E, Raes D. 2012. Crop yield response to water. Food and Agriculture Organizations of the United Nations, Rome. DOI: 10.1017/S0014479712001366.

Stirling GR, Moody PW, Stirling AM. 2010. The impact of an improved sugarcane farming system on chemical, biochemical and biological properties associated with soil health. Applied Soil Ecol 46 (3): 470477. DOI: 10.1016/j.apsoil.2010.08.015

Sulaiman AA, Sulaeman Y, Mustikasari N, Nursyamsi D, Syakir AM. 2019. Increasing sugar production in Indonesia through land suitability analysis and sugar mill restructuring. Land 8 (4): 1-17. DOI: $10.3390 /$ land8040061.

Sun R, Zhang X, Guo X, Wang D, Chu H. 2015. Bacterial diversity in soils subjected to long-term chemical fertilization can be more stably maintained with the addition of livestock manure than wheat straw. Soil Biol Biochem 88: 9-18. DOI: 10.1016/j.soilbio.2015.05.007.

Surendran U, Ramesh V, Jayakumar M, Marimuthu S, Sridevi G. 2016. Improved sugarcane productivity with tillage and trash management practices in semi-arid tropical agroecosystem in India. Soil Tillage Res 158: 10-21. DOI: 10.1016/j.still.2015.10.009.

Teshome Z, Fantaye A, Hagos H. 2015. Effect of nitrogen and phosphorus on yield components, yield and sugarcane juice quality parameters of soybean-sugarcane intercropping at Tendaho sugar factory. Biochem Physiol 4 (1): 1-4. DOI: 10.4172/2168-9652.1000151.

Toharisman A, Triantarti. 2016. An overview of sugar sector in Indonesia. Sugar Tech 18 (6): 636-641. DOI: 10.1007/s12355-016-0490-6.

Tortora ML, Naval G, Vera L, de Ullivarri JF, Digonzelli P, Romero E. 2013. Effect of sugar cane trash blanketing on the development of microorganisms of agronomic and environmental interest. Rev Ind Agr de Tucumán 90 (1): 61-68.

Trivelin PCO, Franco HCJ, Otto R, Ferreira DA, Vitti AC, Fortes C, Faroni CE, Oliveira ECA, Cantarella H. 2013. Impact of sugarcane trash on fertilizer requirements for São Paulo, Brazil. Sci Agric 70 (5): 345-352. DOI: 10.1590/S0103-90162013000500009.

Ullah S, Khan EA, Jilani G, Panhwar M, Shakoor N. 2017. Sugarcanesugarbeet intercropping arguments cumulative crop/ sugar production and financial turnovers under enhanced fertilization. Sugar Tech 20 (4): 431-438. DOI: $10.1007 / \mathrm{s} 12355-017-0551-5$.

van Groenigen JW, Lubbers IM, Vos HMJ, Brown GG, De Deyn GB, van Groenigen KJ. 2014. Earthworms increase plant production: a metaanalysis. Sci Rep 4: 6365. DOI: 10.1038/srep06365.

van Horn DJ, van Horn ML, Barrett JE, Gooseff MN, Altrichter AE, Geyer KM, Zeglin LH, Takacs-Vesbach CD. 2013. Factors 
controlling soil microbial biomass and bacterial diversity and community composition in a cold desert ecosystem: Role of geographic scale. PLoS One 8 (6): e66103. DOI: 10.1371/journal.pone.0066103.

Wachendorf C, Potthoff M, Ludwig B, Joergensen RG. 2014. Effects of addition of maize litter and earthworms on $\mathrm{C}$ mineralization and aggregate formation in single and mixed soils differing in soil organic carbon and clay content. Pedobiologia 57 (3): 161-169. DOI 10.1016/j.pedobi.2014.03.001.

Wang WJ, Reeves SH, Salter B, Moody PW, Dalal RC. 2016. Effects of urea formulations, application rates and crop management residue retention on $\mathrm{N}_{2} \mathrm{O}$ emissions from sugarcane fields in Australia. Agric, Ecosyst \& Environ 216: 137-146.

Wang X, Feng Y, Yu L, Shu Y, Tan F, Gou Y, Luo S, Yang W, Li Z, Wang J. 2020. Sugarcane/soybean intercropping with reduced nitrogen input improves crop productivity and reduces carbon footprint in China. Sci Tot Environ 719: 137517. DOI: 10.1016/j.scitotenv.2020.137517. 10.1016/j.agee.2015.09.035.

Waqar A, Shah GM, Bakhat HF, Shadid M, Aslam M, Ashraf MR, Hafeez R, Murtaza B, Rashid MI. 2019. The earthworm species Pheretima hawayana influences organic wastes decomposition, nitrogen mineralization and maize N recovery. Eur J Soil Biol 90: 1-8. DOI: 10.1016/j.ejsobi.2018.11.003.

Yang W, Li Z, Wang J, Wu P, Zhang Y. 2013. Crop yield, nitrogen acquisition and sugarcane quality as affected by interspecific competition and nitrogen application. Field Crops Res 146: 44-50. DOI: 10.1016/j.fcr.2013.03.008

Yang W, Gu S, Xin Y, Bello A, Sun W, Xu X. 2018. Compost addition enhanced hyphal growth and sporulation of arbuscular mycorrhizal fungi without affecting their community composition in the soil. Front Microbiol 9 (169). DOI: 10.3389/fmicb.2018.00169.

Zaccardelli M, De Nicola F, Villecco D, Scotti R. 2013. The development and suppressive activity of soil microbial communities under compost amendment. J Soil Sci Plant Nutr 13 (3): 730-742. DOI: 10.4067/S0718-95162013005000058.

Zari MP. 2015. Ecosystem services analysis: Mimicking ecosystem services for regenerative urban design. Int J Sust Built Environ 4 (1): 145-157. DOI: 10.1016/j.ijsbe.2015.02.004.

Zhang R, Mu Y, Li X, Li S, Sang P, Wang X, Wu H, Xu N. 2020. Response of the arbuscular mycorrhizal fungi diversity and community in maize and soybean rhizosphere soil and roots to intercropping systems with different nitrogen application rates. Sci Tot Environ 740: 139810. DOI: 10.1016/j.scitotenv.2020.139810.

Zhen Z, Liu H, Wang N, Guo L, Meng J, Ding N, Wu G, Jiang G. 2014. Effects of manure compost application on soil microbial community diversity and soil microenvironments in temperate cropland in Cbina. PloS One 9 (10): e108555. DOI: 10.1371/journal.pone.0108555.

Zhu Z, Bai Y, Lv M, Tian G, Zhang X, Li L, Jiang Y, Ge S. 2020. Soil fertility, microbial biomass, and microbial functional diversity responses to four years fertilization in an apple orchard in North China. Hort Plant J 6 (4): 223-230. DOI: 10.1016/j.hpj.2020.06.003. 